\title{
A Comparison of Three Strains of Holstein-Friesian Grazed on Pasture and Managed Under Different Feed Allowances
}

\author{
K. A. Macdonald, ${ }^{* 1}$ G. A. Verkerk, ${ }^{*}$ B. S. Thorrold, ${ }^{\star}$ J. E. Pryce, $\dagger$ J. W. Penno, ${ }^{\star 2}$ L. R. McNaughton, $\dagger$ \\ L. J. Burton, † J. A. S. Lancaster, ${ }^{\star}$ J. H. Williamson, ${ }^{\star}$ and C. W. Holmesł \\ *DairyNZ, Private Bag 3221, Hamilton, New Zealand 3240 \\ †LIC, Private Bag 3123, Hamilton, New Zealand 3240 \\ łInstitute of Veterinary, Animal and Biomedical Sciences, Massey University, Private Bag 11222, Palmerston North, New Zealand 4442
}

\begin{abstract}
This experiment compared Holstein-Friesian (HF) cows of New Zealand (NZ) origin representative of genetics present in the 1970s (NZ70; $\mathrm{n}=45)$ and 1990s (NZ90; $n=60$ ), and a group of HF cows of North American origin with 1990s genetics (NA90; $n=60$ ), which were managed in grazing systems with a range of feeding allowances ( 4.5 to 7.0 t/cow per yr) over 3 yr. The NZ70 cows had the lowest Breeding Worth genetic index and the lowest breeding values for yields of fat, protein, and milk volume; the NZ90 and NA90 cows were selected to have similar breeding values for milk traits and were representative of cows of high genetic merit in the 1990s. The NZ90 cows had a higher milk protein concentration $(3.71 \%)$ than either the NA90 $(3.43 \%)$ or the NZ70 cows (3.41\%), and a higher milk fat concentration $(4.86 \%)$ than the NA90 cows $(4.26 \%)$ with a level similar to the NZ70 cows (4.65\%). The NZ90 cows produced significantly greater yields of fat, protein, and lactose than the NA90 and NZ70 cows. The NZ70 cows had the lowest mean annual body weight $(473 \mathrm{~kg})$ but the highest body condition score (BCS; 5.06). Days in milk were the same for the $2 \mathrm{NZ}$ strains ( $286 \mathrm{~d}$ in milk), both of which were greater than the NA90 cows ( $252 \mathrm{~d}$ in milk). There was no genotype $\times$ environment interaction for combined milk fat and protein yield (milksolids), with NZ90 producing $52 \mathrm{~kg} /$ cow more than the NA90 at all feeding levels. The NZ70 strain had the highest seasonal average BCS (5.06), followed by the NZ90 (4.51) and the NA90 (4.13) strains on a 1 to 10 scale. Body condition score increased with higher feeding levels in the $2 \mathrm{NZ}$ strains, but not in the NA strain. The first-parity cows commenced luteal activity $11 \mathrm{~d}$ later than older cows (parities 2 and 3),
\end{abstract}

Received June 12, 2007.

Accepted December 3, 2007.

${ }^{1}$ Corresponding author: kevin.macdonald@dairynz.co.nz

${ }^{2}$ Current address: Synlait, RD13, Te Pirita Rd., Rakaia, New Zealand. and the NA90 cows commenced luteal activity 4 and $10 \mathrm{~d}$ earlier than the NZ70 and NZ90 cows. Earlier estrus activity did not result in a higher in-calf rate. The NZ70 and NZ90 cows had similar in-calf rates (pregnancy diagnosed to $6 \mathrm{wk} ; 69 \%$ ), which were higher than those achieved by NA90 cows (54\%). Results showed that the NA90 strain used in this experiment was not suitable for traditional NZ grazing systems. Grazing systems need to be modified if the NA90 strain is to be successfully farmed in NZ. The data reported here show that the NA90 cows require large amounts of feed, but this will not prevent them from having a lower BCS than the NZ strains. Combined with poor reproductive performance, this means that NA90 cows are less productive than NZ HF in pasture-based seasonal calving systems with low levels of supplementation.

Key words: strain, Holstein-Friesian, pasture, milk

\section{INTRODUCTION}

The North American (NA) Holstein-Friesian (HF) cow represents a major source of genetic material for high yields of protein, milk, and milk fat plus protein (milksolids; MS; Kolver et al., 2002; Dillon et al., 2006), particularly when supplemented with a mixed-ration diet. To achieve optimal profitability in dairy production, the type of cow selected must be suitable for the production system operated. Dairying systems differ markedly between North America, Europe, and New Zealand (NZ) and as a consequence, dairy selection objectives also differ (Miglior et al., 2005).

The HF cow farmed in NZ was derived from animals imported from the west coast of the United States before 1925. New Zealand then remained closed to further imports until around 1960 (Harris and Kolver, 2001). Selection within this population of dairy cows has led to the development of the NZ HF. The use of overseas $\mathrm{HF}$ semen in NZ since the mid-1980s (for its potential to increase protein production) has led to the introduction of cattle from countries where selection for produc- 
tion traits was made on measurements made in nonpastoral systems (Harris and Kolver, 2001).

Before the $1960 \mathrm{~s}$, milk fat was the main value component, and selection focused on milk and fat yield. In the $1980 \mathrm{~s}$, protein was included in the milk payment system and was also incorporated into the genetic indices, whereas milk volume was penalized. The introduction of an across-breed genetic evaluation system in 1996 encouraged the adoption of a selection index based on profitability, known as Breeding Worth (Harris et al., 1996). The Breeding Worth index includes 1) payment for milk fat plus milk protein minus a cost for milk volume; 2) returns from culls and calves via BW information; and 3) total feed requirements, which are calculated from production information and BW. Breeding worth is expressed as net lifetime profit per $4.5 \mathrm{t}$ of feed DM requirement per year.

In the early 1990s, the NA type of cow was selected for use in NZ because of its potential for high milk and MS production capabilities. However, responses in milk production to increased genetic merit are lower in grassbased, low-input systems than in high-input systems, suggesting that the high-merit cows are unable to consume enough additional feed to express their potential for increased production (Ferris et al., 1999). Nevertheless, it was anticipated that the trend in use of NA $\mathrm{HF}$ would continue in the NZ national herd, despite seasonal dairy systems requiring efficient animal reproductive processes to produce a compact calving. Concern was expressed regarding the suitability of NA HF for such systems because of increased feed requirements and lower levels of reproductive performance (Dillon et al., 2003). Therefore, the ability of the NA $\mathrm{HF}$, selected in nonseasonal confined feeding systems, to fit the NZ dairy system, which requires a 365-d calving interval and a compact calving period, and to produce milk successfully was questioned.

Genetic selection within the outdoor grazing systems of NZ has resulted in HF that are smaller than strains of HF cows in other countries. Moreover, Jersey cows were accepted as more efficient in grazing systems, with more than $90 \%$ of AI in NZ being Jersey semen in 1955. With the introduction of protein into the NZ milk payment and genetic selection system, there was an influx of NA HF genetics, such that from 1980 to 1999 the average percentage of NA genetics in $\mathrm{HF}$ cows increased from 2 to 38\% (Harris and Kolver, 2001). By the early 1990 s, AI with Jersey semen was used on fewer than $30 \%$ of cows, with predominantly $\mathrm{HF}$ semen used on the majority.

In NZ, Australia, many parts of Western Europe, and South America, pasture may be the sole feed of the cow for long periods of the lactation, if not the whole year. In $\mathrm{NZ}$, farming systems have evolved to capture seasonal patterns of pasture growth by adopting a compact calving in spring, in an endeavor to match the seasonal supply of pasture and herd intake demands (Bryant, 1986).

A comparison of $\mathrm{NZ}$ and Canadian HF cows (CANZ study) reported by Peterson (1988) showed that NZ HF and Canadian HF had similar genetic merit for MS production; however, northern hemisphere HF genetics have made rapid advances since then, using a large source of superior genetic material for milk and protein production. There was interest in evaluating what genetic progress had been made within the NZ national herd between the 1970s and 1990s, which effectively covered 4 cattle breeding generations. This would also allow for validation of the breeding policies under current farming systems.

The experiment reported here compared 2 strains of NZ HF cows, which had high genetic merit for 1998 (NZ90) and 1975 (NZ70), with NA HF (NA90) of high Breeding Worth (1998), when offered a range of feeding levels. The objectives of this research were to 1) establish whether NA HF dairy cows can be profitably used in NZ pasture-based feeding systems; 2) determine the level of genetic progress in milk production, feed conversion efficiency, fertility, and other characteristics of onfarm profitability that have been made in NZ since 1970 ; 3) establish the importance of genotype $\times$ environment $(\mathbf{G} \times \mathbf{E})$ interactions among the effects of 3 genotypes and differing levels of feed inputs on milk production, efficiency, health, and fertility. A companion study (Horan et al., 2005a) was simultaneously conducted at Moorepark Research Centre, Ireland, to evaluate 3 strains of HF, of which 2 represented animals of NZ and NA origin.

\section{MATERIALS AND METHODS}

This experiment was undertaken at DairyNZ (formerly Dexcel), Hamilton, NZ ( $37^{\circ} 47^{\prime}$ S, $175^{\circ} 19^{\prime}$ E, 40 $\mathrm{m}$ above sea level). Over $5 \mathrm{yr}, 3$ strains of HF were reared and physical measurements were recorded from arrival at DairyNZ in 1999 until May 2004 (Macdonald et al., 2007).

\section{Animals}

The animals were sourced as calves born to planned matings on DairyNZ farms and commercial dairy farms within NZ. Cows for contracted mating were selected based on HF percentage, genetic merit determined by the Breeding Worth index, parentage information (including recorded ancestry), and fit of the pedigree to the objectives of the strain. Dams selected were required to have been milk recorded and to have at least 3 genera- 
Table 1. Estimated breeding values and Breeding Worth ${ }^{1}$ (SD) calculated in November 1999 for 3 strains of Holstein-Friesians

\begin{tabular}{lrrr}
\hline & \multicolumn{3}{c}{ Treatment $^{2}$} \\
\cline { 2 - 4 } Item & \multicolumn{1}{c}{ NZ70 } & \multicolumn{1}{c}{ NZ90 } & \multicolumn{1}{c}{ NA90 } \\
\hline Milk fat, kg & $12(8.8)$ & $40(5.5)$ & $36(5.0)$ \\
Protein, kg & $9(8.2)$ & $38(4.6)$ & $44(3.7)$ \\
Milk, kg & $495(223.2)$ & $1,072(162.4)$ & $1,362(139.5)$ \\
BW, kg & $47(14.8)$ & $49(8.7)$ & $83(7.2)$ \\
Breeding Worth & $-10(21.9)$ & $86(11.9)$ & $84(9.3)$ \\
\hline
\end{tabular}

${ }^{1}$ Breeding Worth is expressed as net lifetime profit $(\$) / 4.5 \mathrm{t}$ of feed DM requirement per yr.

${ }^{2}$ Treatments: NZ70 = a 1970s high Breeding Worth strain of New Zealand Friesian; NZ90 = a 1990s high Breeding Worth HolsteinFriesian of New Zealand origin; NA90 = a 1990s high Breeding Worth Holstein-Friesian of North American origin.

tions of pedigree data available. There was an avoidance of dominance by individual sire lines in the dam pedigrees and in sires selected. Estimated breeding values for the animals used are shown in Table 1 . The 3 strains developed are described below.

NZ70 Strain. The NZ70 is a 1970s strain of NZ Friesian with high genetic merit for combined yield of fat and protein for 1975, but low relative to the genetic merit of strains in 1998. The strain was representative of the selection and breeding policies in NZ in the 1970s, and was generated by using semen set aside from that era by LIC (formerly, Livestock Improvement Corporation, Hamilton, NZ). Dams were representative of the cows in the NZ population in the 1970s selected for high milk fat yields. The sires selected had lower EBV for milk fat $(12 \mathrm{~kg})$, protein $(9 \mathrm{~kg})$, and milk (495 kg) than the sires being used in the national herd in the 1990 s. Thirteen sires were used, with $92 \%$ of the NZ70 trial cows being progeny from 9 of these sires. These animals had an average of $\leq 7 \%$ NA HF genetics.

NZ90 Strain. The NZ90 strain was of NZ origin and was selected for high genetic merit of combined fat and protein yield. The strain was generated by using sires and dams with a low proportion of recent NA genetics, and was representative of the $1990 \mathrm{~s} \mathrm{NZ}$ selection and breeding policies, such that they had EBV for milk $(1,072 \mathrm{~kg})$ and BW $(49 \mathrm{~kg})$. Ten sires were used, with $93 \%$ of the NZ90 cows being progeny from 6 of these sires. These animals had an average of $\leq 24 \%$ NA genetics.

NA90 Strain. The NA90 strain was selected for high genetic merit of combined fat and protein yield from animals of NA origin. The NA definition includes sires of NA ancestry but originating from the Netherlands. The strain was established by breeding cows born in NZ, but with a high proportion of overseas genetics in their ancestry, to sires sourced from overseas (these sires' 3 -generation pedigrees could be traced back to
NA). The sires were representative of those being imported into NZ at the time and had higher EBV for milk $(1,362 \mathrm{~kg}), \mathrm{BW}(83 \mathrm{~kg})$, and protein $(44 \mathrm{~kg})$ than the other 2 strains. Sixteen sires were used, with $90 \%$ of the NA90 cows being progeny from 6 of these sires. These 6 sires were the main sires being used as sires of sons for LIC's sire-proving scheme. These animals had an average of $\geq 91 \%$ NA genetics.

The sires used in this study (except for the NZ70) have also been used in other genotype studies representing NZ90 and NA90 genetics (Harris and Kolver, 2001; Horan et al., 2005a,b; Kolver et al., 2007).

At the start of the experiment, the Breeding Worths were $-\$ 10,+\$ 86$, and $+\$ 84$ for the NZ70, NZ90, and NA90, respectively (Table 1; LIC, November 1999). With additional information, the EBV are updated every $12 \mathrm{mo}$, and as a result, a new Breeding Worth value was assigned to every animal.

In the first year, there were 12 cows in each NZ70 farmlet and 17 in each of the NZ90 and NA90 farmlets. For yr 2 and 3, these increased to 15 in the NZ70 and 20 for the NZ90 and NA90 treatments, with the farmlets expanded to maintain the original comparative stocking rate (CSR). There were 3 NZ70 farmlets and 4 farmlets each for the NZ90 and NA90. When an animal died or had to be replaced, and it was considered to be because of a nontreatment effect, it was replaced by a comparable animal [yr $1, \mathrm{n}=0 ; \mathrm{yr} 2, \mathrm{n}=6(\mathrm{NZ70}=1$, $\mathrm{NZ90}=2, \mathrm{NA} 90=3) ; \mathrm{yr} 3, \mathrm{n}=10(\mathrm{NZ70}=2, \mathrm{NZ90}=4$, and NA90 = 4)], but data from the replacement animals were not included in the analyses.

\section{Cow Management}

Rearing, growth, development, and puberty of the heifers were described previously by Macdonald et al. (2007). At 22 mo of age, the heifers were allocated to treatments in a farmlet (small farms within a farm) study at DairyNZ No. 2 Dairy, a 100-ha research dairy farm. Heifers (within strain) were randomly allocated to one of the feed allowance treatments in a completely randomized design, ensuring that treatment groups were balanced for sire, due calving date, BW, and Breeding Worth. The paddocks within the farm were blocked by past treatments and soil type, and within those blocks they were randomly assigned to each farmlet. Paddock allocation was checked to ensure that cows on all farmlets had a similar distance to walk to the dairy. Paddocks were 0.4046 ha (8 to 14 paddocks per farmlet; Table 2) and were grazed in a rotational order, with the cows having access to a fresh allocation of pasture once daily. During the experiment, the animals were managed under a common set of decision rules (Macdonald and Penno, 1998). These decision 
Table 2. Feeding allowance applied to and number of paddocks for each treatment in yr 2 and 3

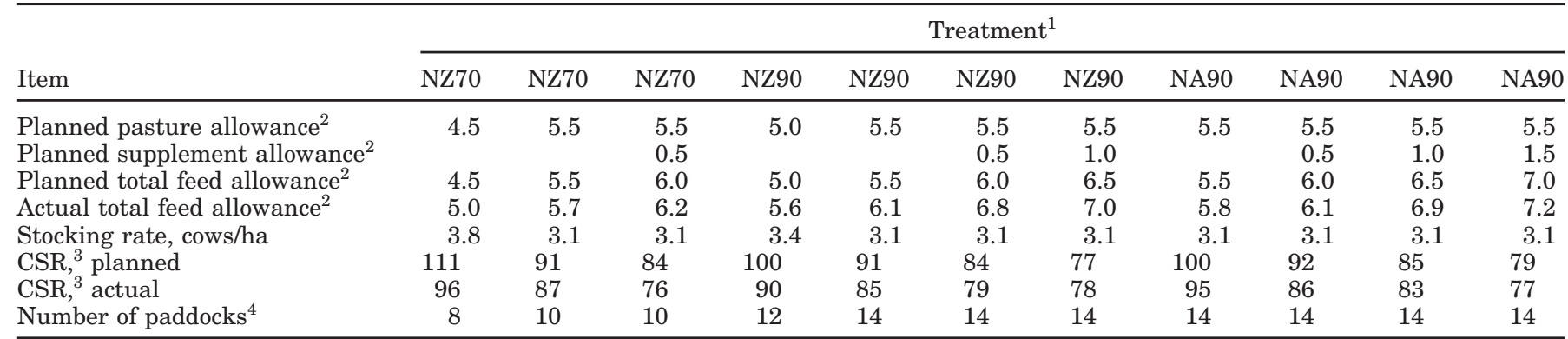

${ }^{1}$ Treatments: NZ70 = a 1970s high Breeding Worth strain of New Zealand Friesian; NZ90 = a 1990s high Breeding Worth HolsteinFriesian of New Zealand origin; NA90 = a 1990s high Breeding Worth Holstein-Friesian of North American origin.

${ }^{2}$ Annual feed allowance ( $t$ of DM/cow per yr).

${ }^{3} \mathrm{CSR}=$ comparative stocking rate $(\mathrm{kg}$ of $\mathrm{BW} / \mathrm{t}$ of $\mathrm{DM})$.

${ }^{4}$ Paddock size, 0.4046 ha.

rules were designed to optimize cow performance at stocking rates (SR) that were high enough to achieve good rates of pasture utilization, and were primarily used to ensure that research farmlets were treated independently and consistently both within and between years. Application of these rules required many of the variables within the dairy farming system to be quantified, thereby removing subjectivity from management decisions.

\section{Feed Allowances}

The feeding systems were designed to provide total annual feed allowances of 4.5 to $7.0 \mathrm{t}$ of $\mathrm{DM} / \mathrm{cow}$, based on different SR and supplement inputs. Eleven farmlet systems were spread across 6 feed allowances, as shown in Table 2. Stocking rates are expressed as cows per hectare and as CSR (kg of BW/t of DM offered). Comparative stocking rate has been developed as a better measure of SR in pasture systems because it takes account of differences in cow BW and includes all feeds offered (Macdonald et al., 2008). Thus, CSR is calculated as the BW per hectare divided by the total amount of feed available per hectare (pasture grown plus other feeds offered). In the present study, CSR were planned to range from 79 to $111 \mathrm{~kg}$ of BW/t of DM. This was calculated from an expected average annual pasture growth of $17 \mathrm{t}$ of DM/ha. A range of allowances were allocated to each strain at which they were expected to be farmed successfully, ranging from moderate feed restriction up to generous feeding levels (4.5 to $7.0 \mathrm{t}$ of $\mathrm{DM} /$ cow per yr; Table 2). Evidence from a previous experiment (Macdonald et al., 2001) indicated that the economically optimum CSR was between 85 and $90 \mathrm{~kg}$ of BW/t of DM. Thus, the CSR for this experiment were set to range below and above this optimum point. The CSR for the herds were calculated from predicted average produc- tion per cow (based on production breeding values), with appropriate adjustments for herd structure. The lowest CSR for each strain were similar, but the feed allowances differed. This took account of the NA90 cows being heavier and needing a higher feed allowance than the other 2 strains. All 3 strains were represented at feed allowances of 5.5 and $6.0 \mathrm{t}$ of $\mathrm{DM} /$ cow per yr. At feed allowances higher than $5.5 \mathrm{t}$ of $\mathrm{DM} /$ cow, additional feed was brought in as either maize silage or maize grain. At the end of each season, $25 \%$ of cows in each herd were culled and replaced with rising $2 \mathrm{yr}$ olds. In the first year of the trial (2001 to 2002), the cows were all 2 yr old, in 2002 to 2003 the herds comprised $75 \% 3 \mathrm{yr}$ olds and $25 \% 2 \mathrm{yr}$ olds, and in 2003 to 2004 the herds comprised 55\% 4-yr-old, 20\% 3-yr-old, and $25 \% 2$-yr-old animals. The opportunity for voluntary culling depended on the level of involuntary culling required in each herd.

\section{Data Measurements and Analyses}

Pasture Measurement. Pasture herbage mass was estimated weekly by 2 people using calibrated visual assessment of each paddock. On each occasion, 11 calibration quadrats (each $0.3 \mathrm{~m}^{2}$ ), representing the range of herbage mass present, were set out. These quadrats were visually assessed for herbage mass ( $\mathrm{kg}$ of $\mathrm{DM} / \mathrm{ha}$ ) before and after the visual assessment of each paddock. The quadrats were then cut to ground level, washed, and dried in a forced-air oven at $97^{\circ} \mathrm{C}$ for $48 \mathrm{~h}$. The visual herbage mass estimate for each paddock was then adjusted by using a regression of quadrat visual assessment on quadrat herbage mass. The net herbage accumulation was calculated weekly from the increase in herbage mass on ungrazed paddocks. In addition, throughout the trial, one person visually assessed pas- 
ture herbage mass before and after grazing of individual paddocks on $3 \mathrm{~d}$ each wk.

Pasture samples were hand clipped (monthly) to represent the grazing strata from the grazing area of each treatment group. Samples were oven-dried at $60^{\circ} \mathrm{C}$, ground, and analyzed for chemical composition by nearinfrared reflectance spectroscopy (Corson et al., 1999). Averaged over the length of the experiment, pasture offered to cows contained $22.4 \pm 3.58 \%$ of DM ADF, 40.8 $\pm 5.24 \%$ of DM NDF, $23.7 \pm 3.34 \%$ of DM CP, and 2.73 $\pm 0.22 \mathrm{Mcal}$ of $\mathrm{ME} / \mathrm{kg}$ of DM.

BCS, BW, and Milk Measurements. Cows were weighed and BCS was assessed in the morning every second week. During periods of feed shortage in the summer to autumn, cows were weighed and BCS was assessed weekly. At calving, cows were weighed and BCS was assessed as soon as practical after parturition. Cows were weighed on a Tru-Test weigh platform (TruTest, Palmerston North, NZ). Body condition score was estimated on a 10-point scale, where 1 is emaciated and 10 is obese (Macdonald and Roche, 2004). These scores can be converted to the 5-point scale of the United States and Ireland by using the regression equations (United States $=1.5+0.32 \mathrm{NZ}$; Ireland $=0.81+0.4$ NZ) reported by Roche et al. (2004).

Milk volume and composition (fat, protein, and lactose) of all cows were measured by weekly herd test. Tru-Test inline milk meters (milk meter system, TruTest) were used to take a representative subsample of $2.5 \%$ of the total milk yield of each cow. A subsample representative of the morning and afternoon milk was analyzed to determine fat, protein, and lactose content by a calibrated Fossomatic FT120 instrument (Foss Electric, Hillerød, Denmark).

Animal Health. From 3 wk before the planned start of calving (PSC) until calving was completed in each farmlet, the pastures grazed by the pregnant cows were dusted with magnesium oxide (70 g/cow per d) for prevention of hypomagnesemia. After calving, the cows were orally drenched with $20 \mathrm{~g}$ of $\mathrm{Mg}$ supplement/d (once daily in the first year and twice daily in the second and third years), in the form of magnesium chloride $\left(\mathrm{MgCI}_{2} \cdot 6 \mathrm{H}_{2} 0\right)$ until late November. During periods of bloat in the spring, an antibloating solution (Bloatenz 2 in 1, Ecolab, Hamilton, NZ) was added to the magnesium chloride solution.

Zinc sulfate ( $8 \mathrm{~g}$ of $\mathrm{ZnSO}_{4} \cdot 7 \mathrm{H}_{2} \mathrm{O} / \mathrm{kg}$ of BW) was given to the cows (orally) during periods of increased vulnerability to facial eczema, as determined by pasture fungal (Pithomyces chartarum) spore counts. In yr 3, one NA90 cow was affected by endophyte-related ryegrass staggers. The cow was removed from pasture for $5 \mathrm{~d}$ and fed pasture silage until clinical signs disappeared, then returned to her treatment group.
Reproduction. Heifers were mated to Jersey bulls to minimize the risk of dystocia. Lactating cows were inseminated with semen from their own strain using 5 sires per strain. These sires were selected on the basis of combined yield of fat and protein and total Breeding Worth (in the case of the two 1990s strains). Bulls with semen stocks still available from the late 1970s to early 1980s were selected to mate to the 1970 s strain. Matings of close relatives (coancestry less than $6.25 \%$ ) were avoided. In the first year, uterine involution was assessed by rectal palpation on d $28 \pm 3$ (SD) postpartum. Assessment was subjective and used a grading from 1 to 4 , where 1 represents a tract in which the cervix and uterine body are fully involuted and 4 represents a situation in which involution is poor and there is palpable evidence of fluid present in the tract. Estrus detection was performed by twice-daily visual observation of estrus behavior at milkings. In addition, all cows were tail-painted (Macmillan et al., 1988) from the first of August or during the first week after they calved. Tail paint was inspected weekly and reapplied if necessary. All observed estrus events were recorded. Any cow that had not been positive for milk progesterone by 1 wk before planned start of mating (PSM) and had calved $>35 \mathrm{~d}$ was treated to induce estrus ovulation. When cows calved within 35 d of PSM, they were treated if they had not had a positive progesterone result as they reached $35 \mathrm{~d}$ postpartum. This was done by insertion of an intravaginal controlled internal drug-releasing device (CIDR; InterAg, Hamilton, NZ) for $6 \mathrm{~d}$, followed by an injection of $1 \mathrm{mg}$ of estradiol benzoate (Intervet Ltd., Auckland, NZ) $24 \mathrm{~h}$ after CIDR removal. Artificial insemination was performed for the first $7 \mathrm{wk}$ from PSM, followed by a further 5 wk of natural breeding with fertile bulls. Pregnancy diagnosis was performed by ultrasound $2 \mathrm{wk}$ before the end of the mating period and again at $5 \mathrm{wk}$ after the end of the 12 -wk mating period. The PSM was brought forward by $1 \mathrm{wk}$ for the second and subsequent seasons, because the experience of yr 1 indicated that this would better match cow demand with pasture growth.

Mastitis. Single foremilk samples were collected from quarters for bacteriological culture at the 10th milking after calving, at drying off, and on 2 other occasions during the lactation. These occasions coincided with peak midlactation (October to November) and midlate lactation (January to February). All cows were checked daily for clinical signs of mastitis during the colostrum period (first $5 \mathrm{~d}$ after calving) and at weekly intervals during the rest of the season. Clinical signs of mastitis included clots or flecks in the milk, discolored milk, heat, pain, or swelling of the udder. All clinical infections were treated with a course of lactating cow intramammary antibiotics, and all quarters were in- 
fused with dry cow antibiotics at the end of lactation. All cows were teat-sprayed with an approved iodinebased sanitizer after every milking. Somatic cell counts were determined by using a Fossomatic automated cell counter (DK-3400, Foss Electric) on cow-composite herd test samples collected every second week throughout the experiment.

Bacteriological Procedures. Quarter foremilk samples were analyzed by using standard mastitis laboratory techniques (National Mastitis Council, 1999). Before collection, teat ends were scrubbed with cottonwool swabs soaked in 70\% alcohol and allowed to dry. The first 2 to 3 squirts of milk were then discarded and approximately $20 \mathrm{~mL}$ was drawn into a sterile container. A subsample of $0.01 \mathrm{~mL}$ of milk was plated onto one quadrant of a tryptose blood agar plate, containing whole bovine blood $(50 \mathrm{~mL} / \mathrm{L})$ and esculin $(1 \mathrm{~g} / \mathrm{L})$, and incubated at $37^{\circ} \mathrm{C}$ for $48 \mathrm{~h}$ before examination. Presumptive identification of isolates was based on colony morphology, hemolysis, esculin reaction, Gram stain, catalase production, and tube coagulase reaction. Confirmatory identification of streptococcal isolates was carried out by using the CAMP test, inulin reaction, growth in $6.5 \%$ salt broth, and hydrolysis of sodium hippurate. Staphylococcal isolates were classified on the basis of hemolysis and tube coagulase reaction as either Staphylococcus aureus or CNS. Gram-negative organisms were identified on the basis of Gram stain, growth on MacConkey agar, lactose fermentation, triple sugar iron-slant reaction, oxidase reaction, citrate utilization, and motility response.

\section{Calculations and Statistical Analysis}

For the analysis of milk, milk components, BCS, and $\mathrm{BW}$, statistical comparisons among feeding levels were not valid in the first year of the experiment because all cows were $2 \mathrm{yr}$ olds and the targeted CSR were not achieved, being similar for treatments within strain. Thus, only data for yr 2 and 3 (2002 to 2003, 2003 to 2004) were statistically analyzed. For reproductive measurements, data for all $3 \mathrm{yr}$ were analyzed among strains because statistically significant differences among feeding groups were not found.

The model fitted was

$$
\begin{aligned}
& y_{i j k l m n p q r s}=\mu+\text { age }_{i}+\text { lactation }_{j}+\text { strain }_{k} \\
& + \text { season }_{l}+b_{m} t d m+\text { strain. }_{n} t d m+\text { strain. }_{P} t d m \cdot \mathrm{tdm} \\
& +F S_{q}+\text { cow }_{r}+\text { err }_{i j k l m n p q r s}
\end{aligned}
$$


Table 4. Production means evaluated at $6 \mathrm{t}$ of DM (by model) offered per cow across seasons 2002 and 2003 for 3 strains of Holstein-Friesians

\begin{tabular}{|c|c|c|c|c|c|c|c|}
\hline \multirow[b]{2}{*}{ Item } & \multicolumn{3}{|c|}{ Treatment $^{1}$} & \multicolumn{4}{|c|}{$P$-value } \\
\hline & NZ70 & NZ90 & NA90 & $\mathrm{SED}^{2}$ & $\mathrm{~S}^{3}$ & $\mathrm{~F}^{4}$ & $\mathrm{Y}^{5}$ \\
\hline Protein, $\%$ & 3.41 & 3.71 & 3.43 & 0.006 & $<0.001$ & $<0.001$ & $<0.001$ \\
\hline Milk fat, \% & 4.65 & 4.86 & 4.26 & 0.124 & $<0.001$ & NS & $\mathrm{NS}$ \\
\hline Milk, kg & 4,811 & 5,593 & 5,479 & 209.1 & $<0.001$ & $<0.001$ & $<0.001$ \\
\hline Milk fat, kg & 218 & 264 & 228 & 9.2 & $<0.001$ & $<0.001$ & $<0.001$ \\
\hline Protein, kg & 162 & 204 & 187 & 7.2 & $<0.001$ & $<0.001$ & $<0.001$ \\
\hline Lactose, $\mathrm{kg}$ & 234 & 271 & 263 & 10.3 & $<0.001$ & $<0.001$ & $<0.001$ \\
\hline $\mathrm{BW}, \mathrm{kg}$ & 473 & 487 & 503 & 10.5 & $<0.001$ & $<0.01$ & $<0.001$ \\
\hline $\mathrm{BCS}^{6}$ & 5.06 & 4.51 & 4.13 & 0.101 & $<0.001$ & $<0.001$ & $<0.001$ \\
\hline Lactation length, d & 286 & 286 & 252 & 5.6 & $<0.001$ & $<0.001$ & $<0.001$ \\
\hline
\end{tabular}

\footnotetext{
${ }^{1}$ Treatments: NZ70 = a 1970s high Breeding Worth strain of New Zealand Friesian; NZ90 = a 1990s high Breeding Worth Holstein-Friesian of New Zealand origin; NA90 = a 1990s high Breeding Worth HolsteinFriesian of North American origin.

${ }^{2}$ Standard error of the difference.

${ }^{3} \mathrm{~S}=$ effect of strain.

${ }^{4} \mathrm{~F}=$ effect of feed allowance.

${ }^{5} \mathrm{Y}=$ effect of year.

${ }^{6}$ Annual mean BCS on a 10-point scale.
}

the 3 strains (NZ90, NZ70, and NA90), season was the fixed effect of season of the trial (2002 and 2003), and tonnes of DM was the feeding level (4.5 to 7.0). The random effects were a farmlet $\times$ season effect $(F S ; n=$ 22 ) and cow. The FS variance was fixed at $1 / 100$ th of the total variance. In studies in which farmlet variance has been estimated, the farmlet variance has been reported to be $<10 \%$ of the animal variance (Fisher, 1999). The model was run fixing farmlet variance at different levels, and the predictions from the model appeared to be robust within the confidence intervals. If the farmlet variance was not fixed, ASReml software (Gilmour et al., 2002) was not able to estimate farmlet variance, because there were only 11 farmlets.

The data were analyzed in ASReml by using a series of univariate animal models (Gilmour et al., 2002). A pedigree was fitted to estimate means for production traits, BW, and BCS.

For production values, overall means were estimated at $6.0 \mathrm{t}$ of $\mathrm{DM}$ offered/cow and averaged over the levels of the fixed effects of lactation number and season. A total of 198 (2002 to 2003) and 195 (2003 to 2004) cow records were used in the analysis of milk production, made up of 45, 79, and 74 (2002 to 2003) and 45, 77, and 73 (2003 to 2004) NZ70, NZ90, and NA90 cows, respectively.

For the analysis of BW and BCS, there were 45, 79, and 74 cows for the NZ70, NZ90, and NA90 strains, respectively, for 2002 (total 198) and 45, 77, and 73 for 2003 (total 195). For the BW and BCS curves, only the animals present from the start of the experiment were used (36, 60, and 60 for the NZ70, NZ90, and NA90 strains, respectively; total of 165).
Means per season by feeding level were predicted by using the model. This analysis was conducted within season and across seasons.

A total of 558 cow records were used in the analysis for reproduction. For analysis of the reproduction data, feeding system was dropped from the model because preliminary analyses showed no significant differences among strains. The difference between the expected calving date (inferred from the last service date) and the actual calving date was calculated, giving a data set of 558 records. The model for analysis was

$$
\mathrm{Y}_{\mathrm{ijkl}}=\operatorname{strain}_{\mathrm{i}}+\text { parity }_{\mathrm{j}}+\text { season }_{\mathrm{k}}+\text { error }_{\mathbf{l}}
$$

Incidence of clinical mastitis (CM) was calculated as the proportion of quarters within a strain group that developed CM during a particular season. Results were pooled across SR groups to provide sufficient numbers for analysis. An individual quarter was counted once only in a single season to eliminate the problem of repeat clinical episodes, so this proportion equated to the proportion of susceptible quarters within a treatment group.

New IMI were identified by the presence of a monoculture of mastitis bacteria of $>500 \mathrm{cfu} / \mathrm{mL}$ in the routinely collected bacteriological samples. The proportion of quarters that developed an IMI with Streptococcus uberis during each season was calculated for each genotype because this pathogen represents the most commonly isolated major mastitis pathogen in NZ. Analysis of genotype effects was by generalized linear model, with binomial error structure (VSN International Ltd., 2007). Individual cow SCC data, determined every 
other week, were first log transformed, averaged for each cow over a particular season, and then analyzed for genotype effects by using ANOVA (VSN International Ltd., 2007).

\section{RESULTS}

Pasture growth was greater than the planned $17 \mathrm{t}$ of $\mathrm{DM} /$ ha per yr, and this had an effect on the actual CSR and actual feed allowances for all treatments. The actual CSR ranged from 76 to $96 \mathrm{~kg}$ of BW/t of DM (Table 2), with the greatest differences between planned and actual CSR and feed allowances at the highest CSR (lowest feed allowances).

Analysis of variance on total lactation milk yield showed that there were effects $(P<0.001)$ of season, age, strain, lactation, and feed allowance (Table 3 ) but no interaction between strain and feed allowance. There were significant differences between the NZ70 and the two 1990s strains (NA90 and NZ90) for milk production traits (Table 4). The NZ90 cows had a higher $(P<0.001)$ protein concentration than both the NA90 and NZ70 cows. The NZ90 had greater fat concentration than the NA90 $(P<0.01)$ but similar to that of the NZ70. The NZ90 cows yielded more fat and protein than the NA90 and NZ70 cows $(P<0.001)$. Lactose yields were similar for the NZ90 and NA90 cows, but were greater $(P<0.001)$ than those of the NZ70 cows. Mean DIM were the same for the $2 \mathrm{NZ}$ strains, but were greater $(P<0.001)$ than for the NA90 cows. As feed allowance increased, milk, milk fat, and protein yields and DIM increased for all strains (Table 3; Figures 1 and 2). There was no difference in lactose concentration between the strains, but the NZ90 and NA90 strains had higher lactose yields than the NZ70 because of their higher milk yield $(P<0.001)$.

Calculated production efficiency ( $\mathrm{kg}$ of $\mathrm{MS} / \mathrm{kg}$ of $\mathrm{BW}^{0.75}$ ) increased with feed allowance (Table 3; $P<$ 0.001). At similar CSR, the NZ90 had a higher efficiency than the NA90, with the NZ70 being the lowest $(P<$ 0.001). At similar actual feed allowances, the ranking was NZ90, NZ70, and NA90.

The NZ70 strain had the highest seasonal average BCS (Table 4 and Figure 3), with the NA90 strain being lowest $(P<0.001)$. The NA90 strain maintained a constant BCS across feeding levels, whereas the BCS of the NZ strains increased with higher feeding levels (Figure 3).

The BW of all cows decreased immediately after parturition (Figure 4), with all strains losing similar amounts, but the NA90 lost more BCS (Figure 5). Days to nadir BCS increased with increasing parity.

The high rate of CIDR use to induce cycling in NZ90 in 2001 (Table 5) was due to a later start of luteal activity and because the PSM for the following year had been brought forward by $1 \mathrm{wk}$ for all strains. Treatment of anestrus was different between the NZ70 and the 21990 strains (NZ90 and NA90) in yr 2, but in yr 3 there was no difference between strains (Table 5). The first-parity cows started cycling later than older cows, whereas the NA90 cows were earlier $(P<0.001)$ than the $2 \mathrm{NZ}$ strains. Gestation length was shorter for the NZ90 cows than for the NZ70 and NA90 cows (Table 5).

There were no differences between strains for uterine involution score at d 28. The NZ70 and NZ90 cows had similar pregnancy-diagnosed in-calf rates to 6 and 8 wk, which were both higher than the NA90 $(P \leq 0.001)$. Heat detection rates did not differ, calculated as the proportion of cows cycled with normal (18 to $24 \mathrm{~d}$ ) vs. twice normal length (39 to $45 \mathrm{~d}$ ).

The NZ90 cows had a greater proportion $(P=0.033)$ of quarters infected with Strep. uberis in the first year (0.07 \pm 0.02 quarters; Table 6), compared with the NZ70 and NA90 cows (both $0.02 \pm 0.01$ quarters).

In the first year, when all animals were first parity, the NA90 cows had the lowest $(P=0.01)$ proportion of quarters that were affected by CM (Table 7). However, by the third year the NA90 cows had the highest proportion $(P<0.005)$ of quarters affected by CM $0.14 \pm 0.02$ (SE) quarters.

Average SCC (cells $/ \mathrm{mL} ; \log _{10} \mathrm{SCC}$ ) for the $3 \mathrm{yr}$ were 4.66, 4.75, and 4.70 for the NZ70, NZ90, and NA90 cows, respectively. The NZ90 cows had a higher $(P<$ 0.005) $\log _{10}$ SCC in December to January in the second year and in December and March to April of the third year. At all other times, there was no difference between strains. Only in yr 3 was there a difference among strains for the seasonal average SCC, with the NZ70 cows having a lower SCC $(P=0.042)$ than the NZ90 cows.

\section{DISCUSSION}

The experiment showed that in NZ, genetic selection during the last $20 \mathrm{yr}$ has resulted in $16 \%$ more milk yield and $23 \%$ more MS yield per cow under pasturebased systems, which is comparable to the gains in production reported for the previous $20 \mathrm{yr}$ between the 1950s and 1970s (Bryant and Trigg, 1981; Davey et al., 1983). This increase in production was reflected by the differences in the breeding values (milk fat, protein, and milk) between the 2 strains (Table 1). Production EBV for the NA90 showed genetic potential, but this was only realized in systems with feeding levels far above typical levels in NZ. Therefore, the NA90 cows required different management to express their NZ EBV. 


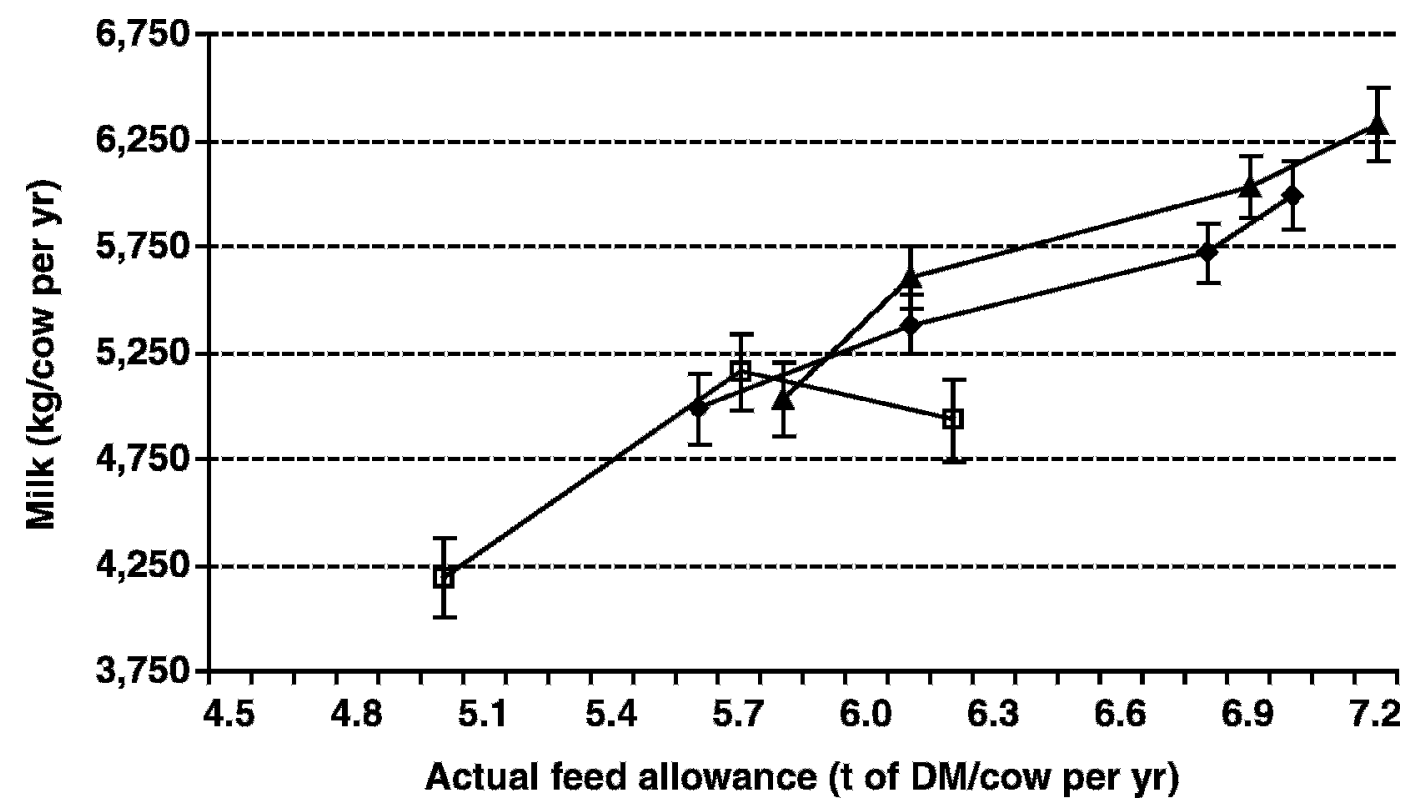

Figure 1. Mean annual milk yield (kg/cow \pm SE) of 3 strains of Holstein-Friesians at differing feeding allowances over 2 seasons. Treatments: $\square$ NZ70 = a 1970s high Breeding Worth strain of New Zealand Friesian; $\bullet$ NZ90 = a 1990s high Breeding Worth HolsteinFriesian of New Zealand origin; $\boldsymbol{\Delta}$ NA90 = a 1990s high Breeding Worth Holstein-Friesian of North American origin.

The milk yield of the NZ70 strain did not increase across the 2 highest feed allowances (Figure 1), whereas for the other 2 strains it continued to increase. This suggests that the NZ70 strain is capable of achieving its genetic potential on pasture, but a very significant shift has occurred to NZ90. The NZ90 strain had a significantly greater milk yield at feed allowances of 5.5 and $6.0 \mathrm{t}$ of DM/cow per yr compared with the NA90 but had numerically less at $6.5 \mathrm{t}$. The slopes appeared to differ for the NA90 and NZ90 strains; however, inter-

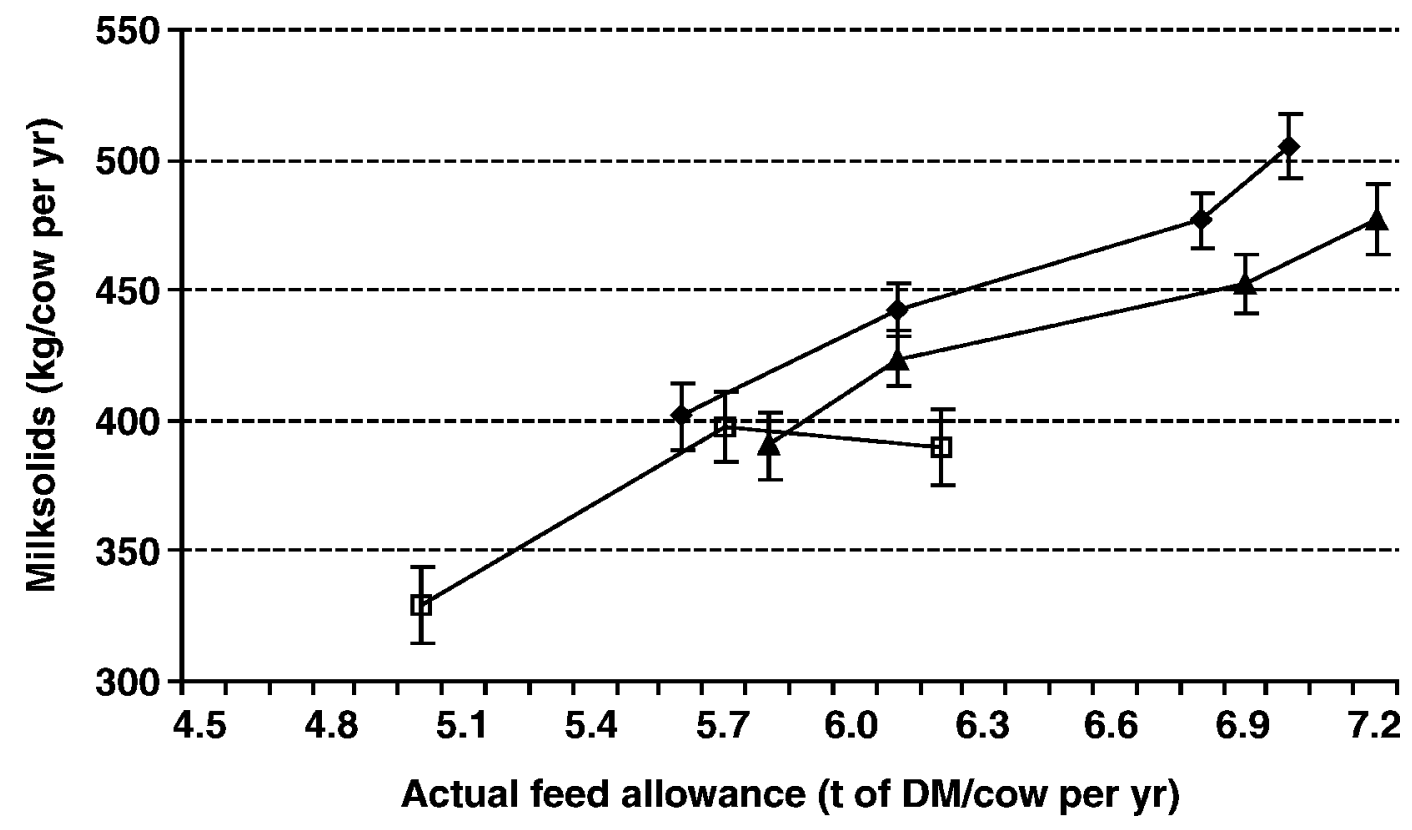

Figure 2. Average annual milksolids (milk fat plus protein) yields (kg/cow \pm SE) of 3 strains of Holstein-Friesians at differing feeding allowances over 2 seasons. Treatments: $\square$ NZ70 = a 1970s high Breeding Worth strain of New Zealand Friesian; $\bullet$ NZ90 = a 1990s high Breeding Worth Holstein-Friesian of New Zealand origin; $\Delta$ NA90 = a 1990s high Breeding Worth Holstein-Friesian of North American origin. 


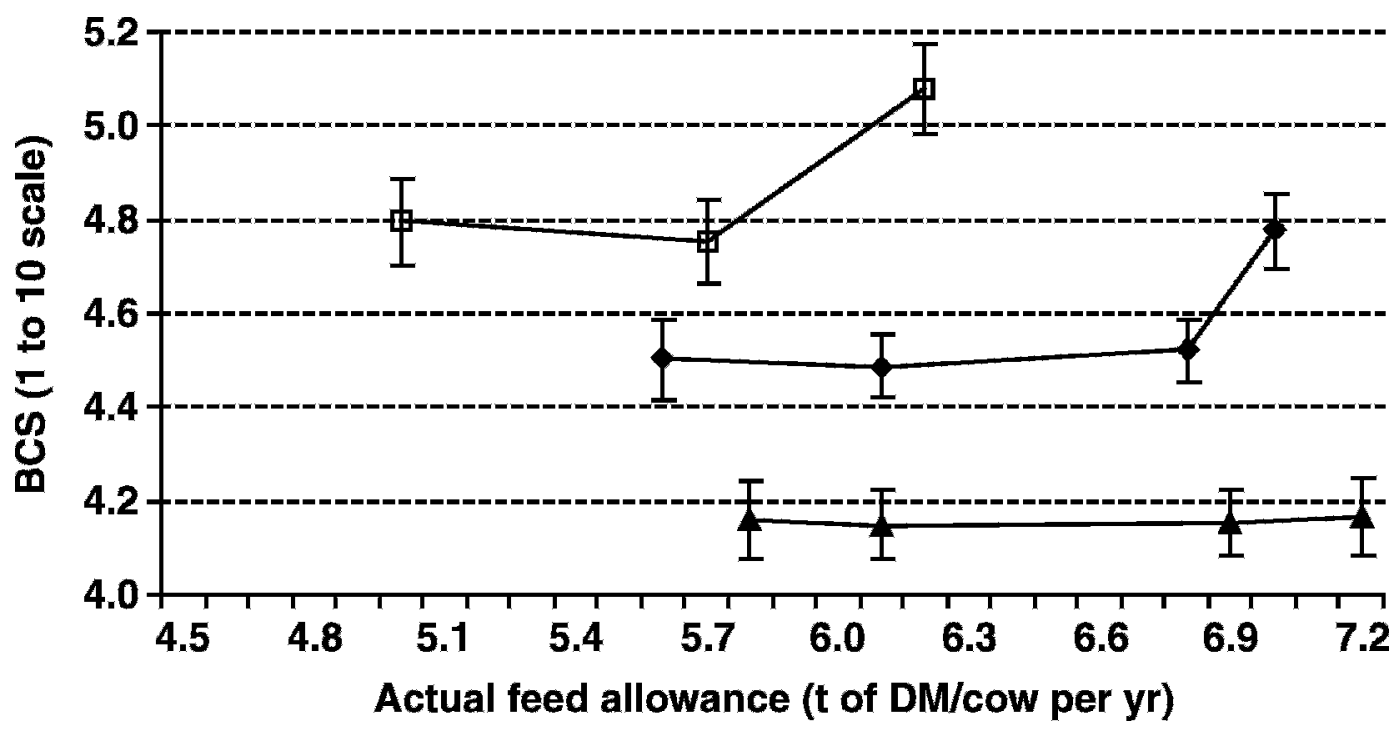

Figure 3. Mean BCS (New Zealand 10-point score \pm SE) of 3 strains of Holstein-Friesians at differing feeding allowances over 2 seasons. Treatments: $\square$ NZ70 = a 1970s high Breeding Worth strain of New Zealand Friesian; NZ90 = a 1990s high Breeding Worth HolsteinFriesian of New Zealand origin; $\boldsymbol{\Delta}$ NA90 = a 1990s high Breeding Worth Holstein-Friesian of North American origin.

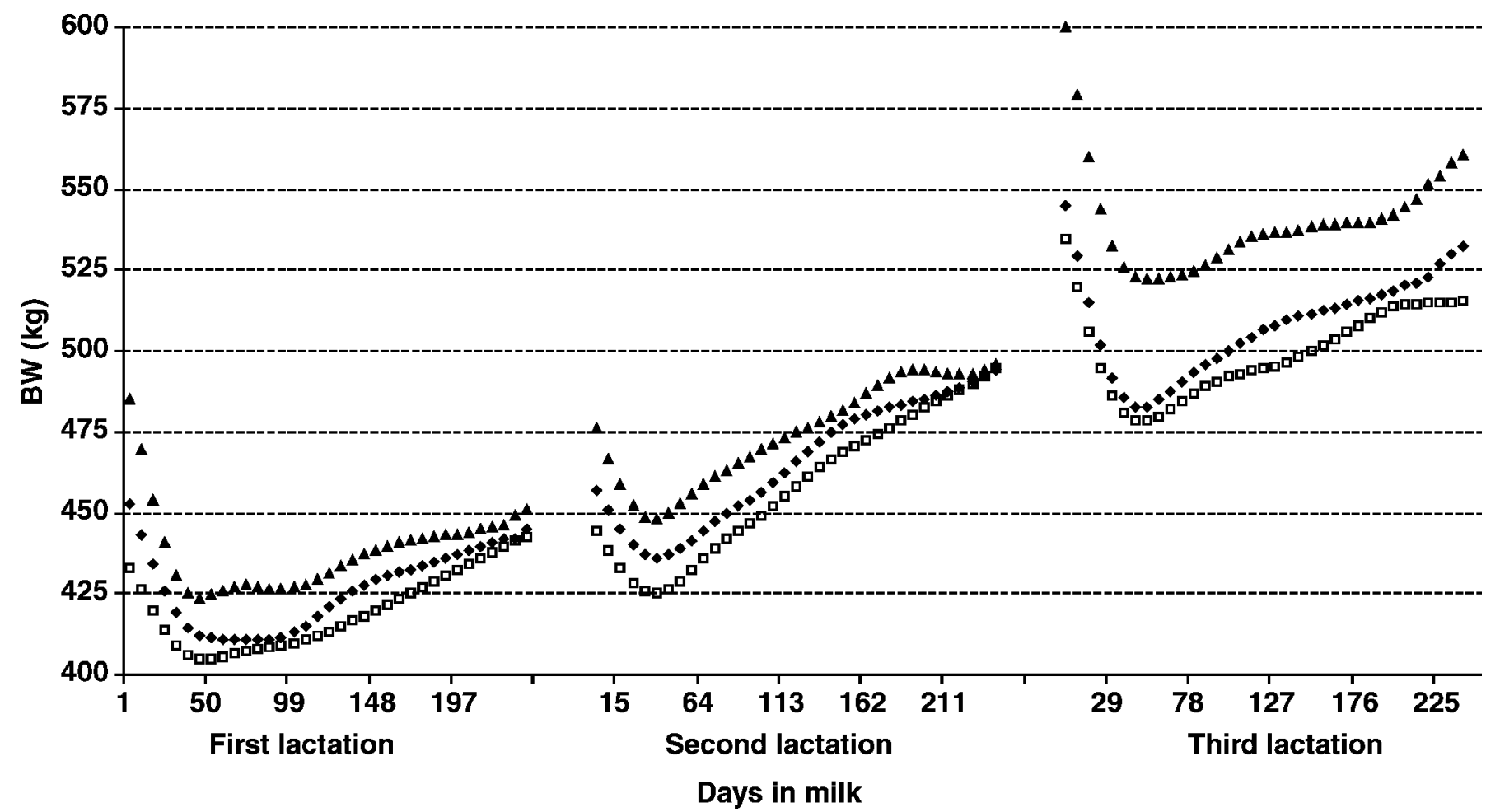

Figure 4. Body weight curves of 3 strains of Holstein-Friesians over 3 lactations for DIM from first calving to near the end of their third lactation. Treatments: $\square$ NZ70 = a 1970s high Breeding Worth strain of New Zealand Friesian; $\bullet$ NZ90 = a 1990s high Breeding Worth Holstein-Friesian of New Zealand origin; $\boldsymbol{\Delta}$ NA90 = a 1990s high Breeding Worth Holstein-Friesian of North American origin. 


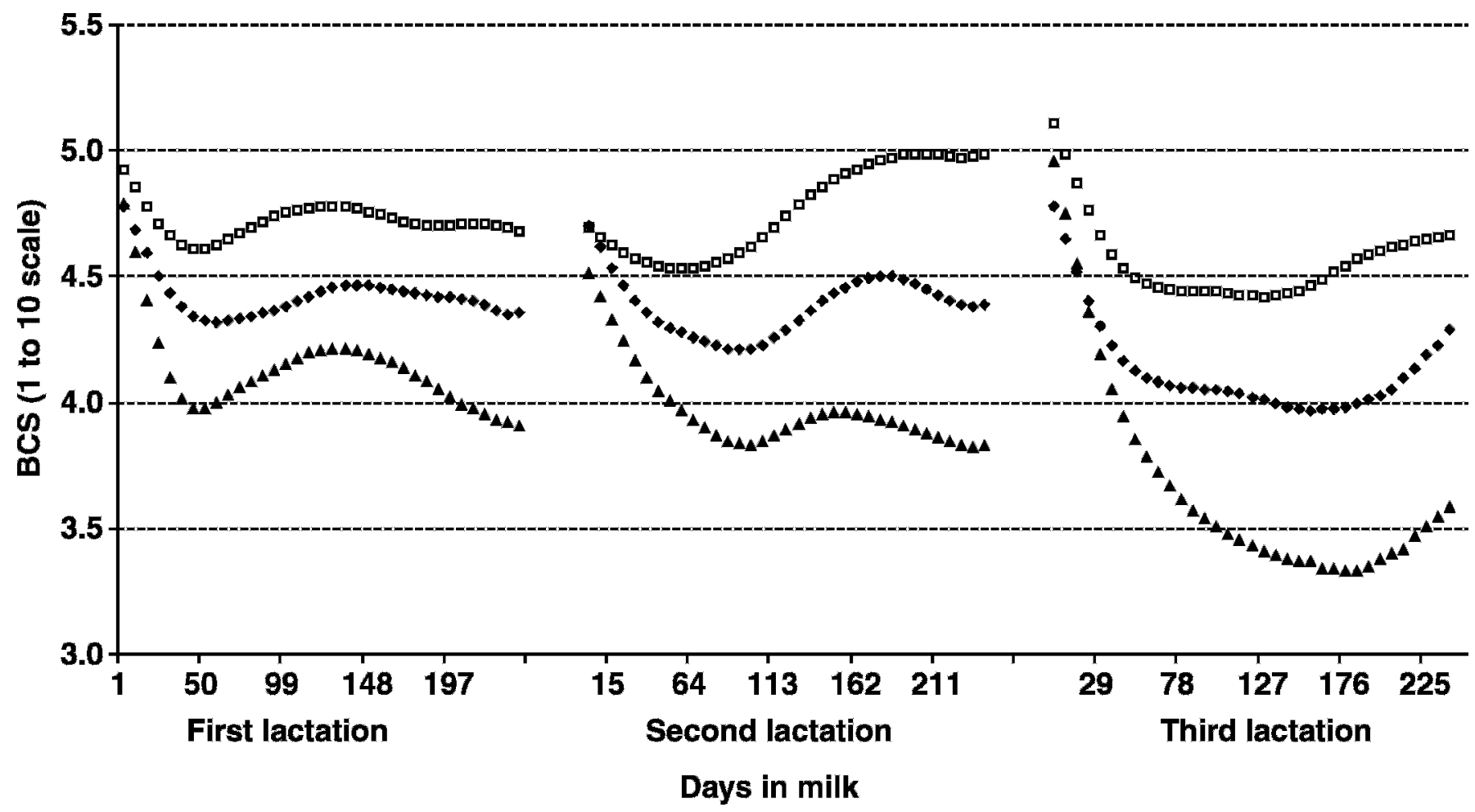

Figure 5. Body condition score curves of 3 strains of Holstein-Friesians over 3 lactations for DIM from first calving to near the end of their third lactation. Treatments: $\square$ NZ70 = a 1970s high Breeding Worth strain of New Zealand Friesian; $\diamond$ NZ90 $=$ a 1990 s high Breeding Worth Holstein-Friesian of New Zealand origin; $\boldsymbol{\Delta}$ NA90 = a 1990s high Breeding Worth Holstein-Friesian of North American origin.

actions between effect of feeding level and strain should be interpreted cautiously because the average interaction effect was not significant. The differences in milk production between the NZ90 and NA90 strains at the lowest feeding levels were not apparent at the high feed allowances; this was in contrast to differences in yields of MS, which were maintained through all feeding levels (Figure 2). This was mainly due to the higher concentrations of fat and protein of the NZ90 cows at all feeding levels.

The differences in MS production between the NA90 and NZ90 strains (Figure 2) were greater than those for milk. The NZ70 and NA90 cows produced similar levels of milk and MS at the lower feed allowances, probably because at this allowance the production potential of the NA90 was constrained by availability of energy for most of the lactation, coupled with higher $\mathrm{BW}$, greater lactose production and BW gain, and lower DMI.

There was no $\mathrm{G} \times \mathrm{E}$ interaction for milk production (Figure 1) or MS, with the MS difference of $52 \mathrm{~kg}$ between the NA90 and NZ90 strains maintained at all feeding levels (Figure 2). The lack of a $\mathrm{G} \times \mathrm{E}$ interaction for MS contrasts with the observation in a farmlet study conducted in Australia, in which the difference in both milk and MS production between cows of high and medium genetic merit increased with increasing levels of concentrate feeding (Fulkerson et al., 2008). In this study, the feed allowances may not have been sufficiently energy dense to allow the NA90 cows to produce to their potential at the highest allowance levels and thus demonstrate a $\mathrm{G} \times \mathrm{E}$ interaction, as was observed in a study by Kolver et al. (2002), in which the NA90 cows produced $459 \mathrm{~kg}$ of MS on pasture and $720 \mathrm{~kg}$ on TMR.

Dairy cows of high genetic merit that have been selected under systems of generous feeding may be more severely affected by feed restrictions (as caused by grazing at moderate allowances) than cows of high genetic merit that have been selected in systems based on grazed pastures. Some degree of feed restriction relative to production potential occurs in NZ pasture-based systems at some times of every year. These restrictions can be minimized while still fully utilizing pasture by the well-managed inclusion of supplementary feeds, as occurred for the farmlets with a higher feed allowance.

The NA90 cows had a lower efficiency ( $\mathrm{kg}$ of MS/kg of $\mathrm{BW}^{0.75}$ ) than the NZ70 and NZ90 cows at similar feed allowances. The calculated efficiency values were similar to those attained by Kolver et al. (2002) under 
Table 5. Cows conceived to first and second AI and within 6 and 8 wk of planned start of mating (PSM) determined by subsequent calving and interval of PSM to first AI and interval between first and second AI, heat detection rates, and CIDR (controlled internal drug-releasing device) use for 3 strains of HolsteinFriesians

\begin{tabular}{|c|c|c|c|c|}
\hline \multirow[b]{2}{*}{ Item } & \multicolumn{3}{|c|}{ Treatment $^{1}$} & \multirow[b]{2}{*}{$P$-value } \\
\hline & NZ70 & NZ90 & NA90 & \\
\hline \multicolumn{5}{|c|}{ Conception rate to first and second $\mathrm{AI}$} \\
\hline First AI & $0.45 \pm 0.05$ & $0.46 \pm 0.04$ & $0.39 \pm 0.04$ & NS \\
\hline Second AI & $0.54 \pm 0.07$ & $0.48 \pm 0.05$ & $0.44 \pm 0.05$ & NS \\
\hline \multicolumn{5}{|l|}{ Pregnancy diagnosed in calf } \\
\hline Within 6 wk & $0.70 \pm 0.04$ & $0.69 \pm 0.03$ & $0.54 \pm 0.03$ & 0.001 \\
\hline Within 8 wk & $0.80 \pm 0.04$ & $0.75 \pm 0.03$ & $0.62 \pm 0.03$ & 0.001 \\
\hline \multicolumn{5}{|c|}{ Final pregnancy rate, after $12 \mathrm{wk}$ of mating } \\
\hline 2001 & 100 & 100 & 85 & $<0.001$ \\
\hline 2002 & 87 & 87 & 83 & NS \\
\hline 2003 & 95 & 87 & 77 & $<0.05$ \\
\hline Mean pregnancy rate & $0.93 \pm 0.03$ & $0.93 \pm 0.01$ & $0.87 \pm 0.02$ & $<0.05$ \\
\hline PSM to first AI, d & $9.6 \pm 1.1$ & $9.5 \pm 0.8$ & $11.3 \pm 0.9$ & NS \\
\hline Interval first to second $\mathrm{AI}, \mathrm{d}$ & $23.7 \pm 1.3$ & $22.8 \pm 0.94$ & $26.2 \pm 0.97$ & 0.05 \\
\hline PSM to conception, $d$ & $29.3 \pm 2.5$ & $28.4 \pm 1.9$ & $33.6 \pm 2.0$ & NS \\
\hline Heat detection rate & $0.91 \pm 0.06$ & $0.89 \pm 0.04$ & $0.87 \pm 0.04$ & NS \\
\hline \multicolumn{5}{|l|}{ Mean calving date, $d$} \\
\hline 2001 & Aug. $17 \pm 3.8$ & Aug. $21 \pm 3.0$ & Aug. $18 \pm 3.0$ & NS \\
\hline 2002 & Jul. $31 \pm 3.3$ & Aug. $4 \pm 2.6$ & Aug. $5 \pm 2.7$ & NS \\
\hline 2003 & Jul. $30 \pm 3.1$ & Jul. $28 \pm 2.4$ & Aug. $7 \pm 2.5$ & 0.05 \\
\hline \multicolumn{5}{|l|}{ CIDR use, $\%$ of cows treated } \\
\hline 2001 & $63 \pm 0.7$ & $83 \pm 0.6$ & $45 \pm 0.6$ & $<0.001$ \\
\hline 2002 & $15 \pm 0.6$ & $30 \pm 0.5$ & $27 \pm 0.5$ & NS \\
\hline 2003 & $11 \pm 0.6$ & $8 \pm 0.5$ & $3 \pm 0.5$ & NS \\
\hline Gestation length, $d$ & 282.6 & 281.0 & 283.9 & 0.01 \\
\hline
\end{tabular}

${ }^{1}$ Treatments: NZ70 = a 1970s high Breeding Worth strain of New Zealand Friesian; NZ90 = a 1990s high Breeding Worth Holstein-Friesian of New Zealand origin; NA90 = a 1990s high Breeding Worth HolsteinFriesian of North American origin.

a pastoral system, and it was not until a TMR was fed to the cows that the NA cows had a higher level of efficiency. The present data suggest that the NZ90 and NA90 cows, even at the highest feed allowances, were still not able to express their full potential even though the allowances of up to 7.0 and $7.2 \mathrm{t}$ of $\mathrm{DM} / \mathrm{cow}$, respec- tively, were very generous by NZ standards. These results confirm those attained by Kolver et al. (2002).

Research in Northern Ireland has clearly demonstrated the superior milk production potential of $\mathrm{HF}$ cows of high genetic merit in grass-based, low-input systems when compared with Irish Friesians of medium

Table 6. Commencement of luteal activity, measured by progesterone concentration $(\mathrm{ng} / \mathrm{mL})$ in the blood ${ }^{1}$ for 3 strains of Holstein-Friesians

\begin{tabular}{lcccc}
\hline & \multicolumn{3}{c}{ Treatment $^{2}$} \\
\cline { 2 - 4 } Item & NZ70 & NZ90 & NA90 \\
\hline Season & & & \\
2001 & $30.2 \pm 3.94$ & $42.3 \pm 3.94$ & $25.2 \pm 2.65$ & NS \\
2002 & $33.7 \pm 2.81$ & $33.6 \pm 2.37$ & $27.4 \pm 3.32$ & NS \\
2003 & $32.6 \pm 2.46$ & $40.0 \pm 1.93$ & $32.6 \pm 1.99$ & NS \\
Mean & $32.2 \pm 1.79$ & $38.7 \pm 1.62$ & $28.4 \pm 1.29$ & $<0.001$ \\
& & Parity & \\
\cline { 2 - 4 } & 1 & 2 & $27.8 \pm 2.11$ & $<0.001$ \\
\hline
\end{tabular}

${ }^{1}$ The data excluded CIDR (controlled internal drug-releasing device)-treated cows (78, 141, and 181 records were analyzed in 2001, 2002, and 2003, respectively).

${ }^{2}$ Treatments: NZ70 = a 1970s high Breeding Worth strain of New Zealand Friesian; NZ90 = a 1990s high Breeding Worth Holstein-Friesian of New Zealand origin; NA90 = a 1990s high Breeding Worth HolsteinFriesian of North American origin. 
Table 7. Proportion of quarters ( \pm SE) that were recorded with clinical mastitis or an IMI with Streptococcus uberis over 3 successive years for 3 strains of Holstein-Friesians

\begin{tabular}{lcccc}
\hline & \multicolumn{4}{c}{ Treatment $^{1}$} \\
\cline { 2 - 5 } Season & NZ70 & NZ90 & NA90 & $P$-value \\
\hline Clinical mastitis & $0.07 \pm 0.021$ & $0.10 \pm 0.018$ & $0.04 \pm 0.011$ & 0.010 \\
$2001-2002$ & $0.10 \pm 0.022$ & $0.11 \pm 0.018$ & $0.09 \pm 0.016$ & NS \\
$2002-2003$ & $0.05 \pm 0.016$ & $0.10 \pm 0.017$ & $0.14 \pm 0.021$ & $<0.01$ \\
2003-2004 & $0.02 \pm 0.014$ & $0.07 \pm 0.018$ & $0.02 \pm 0.010$ & 0.033 \\
Strep. uberis & $0.02 \pm 0.009$ & $0.02 \pm 0.009$ & $0.02 \pm 0.007$ & NS \\
2001-2002 & $0.02 \pm 0.012$ & $0.05 \pm 0.016$ & $0.07 \pm 0.018$ & NS \\
$2002-2003$ & 2003-2004 &
\end{tabular}

${ }^{1}$ Treatments: NZ70 = a 1970s high Breeding Worth strain of New Zealand Friesian; NZ90 = a 1990s high Breeding Worth Holstein-Friesian of New Zealand origin; NA90 = a 1990s high Breeding Worth HolsteinFriesian of North American origin.

genetic merit (Mayne, 1998), but at a cost of greater losses of BW and BCS. The NA90 cows had similar BCS at all feeding levels, which suggests that in grazing systems they are under a greater energy deficit even at higher allowances. These results are consistent with the data for average BW (over the season). The difference between the $\mathrm{BW}$ at the highest allowance and the lowest allowance was $27 \mathrm{~kg}$ for the NZ90 and only $9 \mathrm{~kg}$ for the NA90.

The greater loss of BCS postcalving by the NA90 indicates that in early lactation, they were in negative energy balance for much longer than the other 2 strains. These results agree with other reports (Horan et al., 2005a) that have shown the NA HF cows lose more BCS postcalving and reach their postcalving nadir BCS and BW later than NZ strains.

In the companion study in Ireland, the NA HF cows also exhibited greater loss of BCS in early lactation than the NZ HF cows, and they failed to gain BCS over the entire lactation (Horan et al., 2005a). Increased feeding levels had no effect on loss of BCS in early lactation, whereas in the present study this was true only for the NA90 cows. In both of the NZ strains, the treatment at higher feeding levels had higher BCS in early lactation because the higher feeding level reduced loss of BCS.

Macdonald et al. (2005) reported that the decision rules developed in farmlet trials in the 1980s and 1990s proved to be robust in optimizing productivity for the $2 \mathrm{NZ}$ strains across a wide range of feed inputs. In the present experiment, these decision rules resulted in NA90 being dried off earlier than NZ90, which resulted in lactation being $34 \mathrm{~d}$ shorter than NZ HF. The NA90 cow functions at a lower BCS than the other 2 strains, and to recalve at an acceptable BCS, the cow needs to be dried off when BCS is below the target. However, the NA90 cows, even at high feed allowances, had shorter lactations, leading to lower profitability and lower feed conversion efficiency. In the third season, new decision rules were implemented that delayed the date at which the threshold BCS triggered drying off, followed by generous feeding after drying-off, which enabled the NA90 cows at the higher feed allowance to be milked for longer without penalizing calving BCS. However, this would only be feasible if adequate feed supplies were available during the dry period to ensure rapid recovery of BCS. If the NA90 continues to be a part of the NZ dairy herd, modifications to feeding systems are required to meet the cows' production potential.

The strict management objectives to initiate estrus when cows fail to cycle by PSM are an integral part of a system in which a compact calving pattern is needed to maximize production in pasture-based systems without the use of calving inductions. Conception rates are known to be lower when estrus is induced ( $\mathrm{Xu}$ and Burton, 2003; McNaughton, 2004), and this makes interpretation of the data for the interval from PSM to first AI difficult. Nevertheless, the results showed that the NA90 resumed estrus activity more quickly after calving (Table 6), but that this did not result in an earlier or higher in-calf rate. This result is supported by McNaughton et al. (2007), who also demonstrated that as long as the animals were cycling at the planned start of mating, there was no advantage to an earlier commencement of luteal activity.

In pasture-based systems, late-calving cows may have the benefit of being better fed than those calving earlier, triggering a faster start to the estrus cycle, suggesting that the shorter postpartum anestrus interval of the NA90 cows may be partly due to calving later. However, in 2001, when the NZ90 strain calved on average $3 \mathrm{~d}$ later than the NA90 strain, the NA90 strain still commenced luteal activity earlier than the NZ90 strain. Verkerk et al. (2000), in a study of HF cows of NZ and NA origin, also reported earlier commencement of luteal activity by the NA HF cows. 
Both the present experiment and that of Horan et al. (2005b) found no significant effect of feeding level on reproductive performance. In the present experiment, possible differences between feeding allowances may have been negated because management decision rules (Macdonald and Penno, 1998) were centered around ensuring that the cows attained adequate BCS at calving, and spring management meant that all cows received feed allowances above the NZ average. Another study in Ireland, comparing HF cows sourced from the United States and the Netherlands with Irish HF cows, also showed that the cows from the former experienced reproductive difficulties (Dillon et al., 2006). The NA90 strain also had longer intervals between the first and second AI, implying embryo loss and longer intervals to cycle again, contributing to their lower pregnancy rates.

The NZ national database shows no evidence of a changing conception rate (Burton et al., 1999) from 1973 to 1996, which was before there was a large increase in overseas genetics within the national HF herd. A NZ study examined efficiencies in 2 lines of HF cows bred for the same Breeding Worth, but selected for heavy or light BW (Laborde et al., 1998). They reported differences in conception rate to first service of 54 and $65 \%$ for heavy and light lines, respectively. The light strain was dominated by NZ HF genetics, whereas the heavy line was dominated by NA HF genetics. Results here are supported by Harris et al. (2006), who showed that for the NZ dairy herd, although there has been no decline in submission rate from 1991 to 2003, conception rate to $42 \mathrm{~d}$ of mating has dropped markedly. The shorter gestation length of the NZ90 compared with the NA90 ( $3 \mathrm{~d}$ ) was also reported by Horan et al. (2005b; $6 \mathrm{~d}$ ), although there is no explanation for the differences recorded in NZ or Ireland.

The increase in proportion of quarters affected by mastitis in the NA90 cows has also been reported by Lacy-Hulbert et al. (2002). The difference among strains also became more apparent as the cows aged, with the greatest differences visible in the third season when at least $50 \%$ of each herd was in its third lactation, in agreement with previous work (Lacy-Hulbert et al., 2002).

High milk production has been associated with an increased incidence of mastitis (Pryce et al., 1999), but in the current trial, there was no difference in milk production between the two 1990 strains, whereas the NZ70 cows yielded significantly less milk in all $3 \mathrm{yr}$. In the third year, the NZ70 strain had the lowest incidence of clinical mastitis and occurrence of IMI with Strep. uberis.

It is not clear why the SCC of the NZ70 were lower than those of the NZ90 in the third lactation, but it could be a legacy of CM in the previous lactation. How- ever, the incidence of CM and IMI by Strep. uberis was generally lower for this strain than for the others in each year of the study. The lack of difference in SCC among the strains has also been reported by Washburn et al. (2002), but the average log SCC was similar to the 4.45 to 4.80 reported by Lacy-Hulbert et al. (2002) for the NA and NZ strains of HF.

\section{CONCLUSIONS}

This experiment showed that genetic improvement from the 1970s to the late 1990s in NZ has increased $\mathrm{HF}$ milk yield by $16 \%$ and MS yield by $23 \%$, and has increased the time between calving and resumption of estrus. Improvement in yields of milk and MS over the last $20 \mathrm{yr}$ are comparable with those of a similar comparison between the 1950s and 1970s. North American HF had a greater BCS loss and lowered fertility and, on pasture only, had no increase in milk yield compared with the NZ70. On the basis of the genetics represented in this study, current farm systems need to be modified to allow the NA90 strain of cow to survive under a NZ pastoral system, where forage makes up nearly $100 \%$ of the diet. The experiment demonstrates that the NA HF strain requires large amounts of feed, but this will not prevent a lower BCS than in the NZ strains. Low BCS in conjunction with lower reproductive performance means that the NA HF are difficult to sustain in traditional pastoral grazing systems with low levels of supplementary feed.

\section{ACKNOWLEDGMENTS}

This study was funded by New Zealand Dairy Farmers through the Dairy InSight research fund (contract number 10082) and Livestock Improvement Corporation (now LIC). It was part of a joint project between DairyNZ, LIC, Massey University, and Teagasc (Moorepark, Ireland). The support of Pat Dillon and other Teagasc staff was welcome. The authors gratefully acknowledge the contribution of Chris Glassey (DairyNZ), and Rob Jackson, Jack Hooper, and David Sellars (LIC), who were all on the consultative committee. The assistance of Barbara Dow (statistics) and the DairyNZ staff, in particular John Milburn (animal management) and Carol-Leydon Davis (data collection), is especially recognized.

\section{REFERENCES}

Bryant, A. M. 1986. Major determinants of milk production from grazed pasture in New Zealand. Int. Dairy Fed. Bull. 199:3-6.

Bryant, A. M., and T. E. Trigg. 1981. Progress report on the performance of Jersey cows differing in breeding index. Proc. N. Z. Soc. Anim. Prod. 41:39-43. 
Burton, L. J., B. L. Harris, A. M. Winkelman, and Z. Z. Xu. 1999. Reproductive performance and genetic improvement of fertility in dairy cattle. Proc. Massey Univ. Dairy-Farming Ann. 51:59-67.

Corson, D. C., G. C. Waghhorn, M. J. Ulyatt, and J. Lee. 1999. NIRS: Forage analysis and livestock feeding. Proc. N. Z. Grassl. Assoc. 61:127-132.

Davey, A. W. F., C. Grainger, D. D. S. MacKenzie, D. S. Flux, G. F. Wilson, I. M. Brookes, and C. W. Holmes. 1983. Nutritional and physiological studies of differences between Friesian cows of high and low genetic merit. Proc. N. Z. Soc. Anim. Prod. 43:67-70.

Dillon, P., D. P. Berry, R. D. Evans, F. Buckley, and B. Horan. 2006. Consequences of genetic selection for increased milk production in European seasonal pasture based systems for milk production. Livest. Sci. 99:141-158.

Dillon, P., S. Snijders, F. Buckley, B. Harris, P. O'Connor, and J. F. Mee. 2003. A comparison of different dairy cows breeds on a seasonal grass-based system of milk production. 2. Reproduction and survival. Livest. Prod. Sci. 83:35-42.

Ferris, C. P., F. G. Gordon, D. C. Patterson, C. S. Mayne, and D. J. Kilpatrick. 1999. The influence of dairy cow genetic merit on the direct and residual responses to level of concentrate supplementation. J. Agric. Sci. (Camb.) 132:467-481.

Fisher, D. 1999. Defining the experimental unit in grazing trials. Proc. Am. Soc. Anim. Sci. jas.fass.org/cgi/reprint/77/E-Suppl/1e.pdf Accessed Jan. 6, 2008.

Fulkerson, W. J., T. M. Davison, S. C. Garcia, G. Hough, M. E. Goddard, R. Dobos, and M. Blockey. 2008. Holstein-Freisian dairy cows under a predominantly grazing system: Interaction between genotype and environment. J. Dairy Sci. 91:826-839.

Gilmour, A. R., B. J. Gogel, B. R. Cullis, S. J. Welham, and R. Thompson. 2002. ASReml User Guide Release 1.0. VSN Int. Ltd., Hemel Hempstead, UK.

Harris, B. L., J. M. Clark, and R. G. Jackson. 1996. Across breed evaluation of dairy cattle. Proc. N. Z. Soc. Anim. Prod. 56:12-15.

Harris, B. L., and E. S. Kolver. 2001. Review of Holsteinization on intensive pastoral dairy farming in New Zealand. J. Dairy Sci. 84 (E Suppl.):E56-E61

Harris, B. L., J. E. Pryce, Z. Z. Xu, and W. A. Montgomerie. 2006. Development of new fertility breeding values in the dairy industry. Proc. N. Z. Soc. Anim. Prod. 66:107-112.

Horan, B., P. Dillon, D. P. Berry, P. O'Connor, and M. Rath. 2005a. The effect of strain of Holstein-Friesian by pasture-based feed system interaction for milk production, body weight, and body condition score. J. Dairy Sci. 88:1231-1243.

Horan, B., J. F. Mee, P. O'Connor, M. Rath, and P. Dillon. 2005b. The effect of strain of Holstein-Friesian cow and feeding system on postpartum ovarian function, animal production and conception rate to first service. Theriogenology 63:950-971.

Kolver, E. S., J. R. Roche, C. R. Burke, J. K. Kay, and P. W. Aspin. 2007. Extending lactation in pasture-based dairy cows: 1. Genotype and diet effect on milk and reproduction. J. Dairy Sci. 90:5518-5530.

Kolver, E. S., J. R. Roche, M. J. De Veth, P. L. Thorne, and A. R. Napper. 2002. Total mixed rations versus pasture diets: Evidence of a genotype $\times$ diet interaction in dairy cow performance. Proc. N. Z. Soc. Anim. Prod. 62:246-251.

Laborde, D., C. W. Holmes, J. G. Garcia-Muniz, and J. Witchel. 1998. Reproductive performance of Holstein-Friesian cows differing genetically in live weight. Proc. N. Z. Soc. Anim. Prod. 58:73-75.

Lacy-Hulbert, S. J., E. S. Kolver, J. H. Williamson, and A. R. Napper. 2002. Incidence of mastitis among cows of different genotypes in differing nutritional environments. Proc. N. Z. Soc. Anim. Prod. 62:24-29.
Macdonald, K. A., L. R. McNaughton, G. A. Verkerk, J. W. Penno, L. J. Burton, D. P. Berry, P. J. S. Gore, J. A. S. Lancaster, and C. W. Holmes. 2007. A comparison of three strains of HolsteinFriesian grazed on pasture: Growth, development, and puberty. J. Dairy Sci. 90:3993-4003.

Macdonald, K. A., and J. W. Penno. 1998. Management decision rules to optimise production on dairy farms. Proc. N. Z. Soc. Anim. Prod. 58:132-135.

Macdonald, K. A., J. W. Penno, J. A. S. Lancaster, and J. R. Roche. 2008. Effect of stocking rate on pasture production, milk production, and reproduction of cows in pasture-based systems. J. Dairy Sci. 91:doi:10.3168/jds.2007-0630

Macdonald, K. A., J. W. Penno, P. K. Nicholas, J. A. Lile, M. Coulter, and J. A. S. Lancaster. 2001. Farm systems-Impact of stocking rate on dairy farm efficiency. 2001. Proc. N. Z. Grassl. Assoc. 63:223-227.

Macdonald, K., and J. Roche. 2004. Condition Scoring Made Easy: Condition Scoring Dairy Herds. 1st ed. Dexcel Ltd., Hamilton, New Zealand.

Macdonald, K. A., B. S. Thorrold, C. B. Glassey, C. W. Holmes, and J. E. Pryce. 2005. Impact of farm management decision rules on the production and profit of different strains of Holstein-Friesian dairy cows. Proc. N. Z. Soc. Anim. Prod. 65:40-45.

Macmillan, K. L., V. K. Taufa, D. R. Barnes, A. M. Day, and R. Henry. 1988. Detecting estrus in synchronized heifers using tailpaint and an aerosol raddle. Theriogenology 30:1099-1114.

Mayne, S. 1998. Selecting the correct dairy cow for grazing systems. Ruakura Dairy Farmers' Conf. 50:45-49.

McNaughton, L. R. 2004. A comparison of reproductive physiology in three strains of Holstein Friesian dairy cattle. PhD Diss. Massey Univ., Palmerston North, New Zealand.

McNaughton, L. R., K. M. Sanders, J. E. Pryce, G. E. Bracefield, S. J. Harcourt, and R. J. Spelman. 2007. Phenotypic relationships between the interval from calving to first luteal activity and fertility in a seasonal dairy production system. Anim. Reprod. Sci. 102:98-110.

Miglior, F., B. L. Muir, and B. J. Van Doormaal 2005. Selection indices in Holstein cattle of various countries. J. Dairy Sci. 88:1255-1263.

National Mastitis Council. 1999. Laboratory Handbook on Bovine Mastitis. Natl. Mast. Counc. Inc., Madison, WI.

Peterson, R. 1988. Comparison of Canadian and New Zealand sires in New Zealand for production, weight and conformation traits. Livest. Improv. Res. Bull. No 5. Livestock Improvement Corp. Ltd., Hamilton, New Zealand.

Pryce, J. E., B. L. Nielsen, R. F. Veerkamp, and G. Simm. 1999. Genotype and feeding system effects and interactions for health and fertility traits in dairy cattle. Livest. Prod Sci. 57:193-201.

Roche, J. R., P. G. Dillon, C. R. Stockdale, L. H. Baumgard, and M. J. VanBaale. 2004. Relationships among international body condition scoring systems. J. Dairy Sci. 87:3076-3079.

Verkerk, G. A., S. Morgan, and E. S. Kolver. 2000. Comparison of selected reproductive characteristics in Overseas and New Zealand Holstein-Friesian cows grazing pasture or fed a total mixed ration. Proc. N. Z. Soc. Anim. Prod. 60:270-274.

VSN International Ltd. 2007. GenStat for Windows. 9th ed. VSN Int. Ltd., Hemel Hempstead, UK.

Washburn, S. P., S. L. White, J. T. Green, Jr., and G. A. Benson. 2002. Reproduction, mastitis, and body condition of seasonally calved Holstein and Jersey cows in confinement or pasture systems. J. Dairy Sci. 85:105-111.

$\mathrm{Xu}, \mathrm{Z}$., and L. Burton. 2003. Reproductive performance of dairy cows in New Zealand. Final report of the monitoring fertility project. Occas. Publ. LIC, Hamilton, New Zealand http://www.aeu.org.nz/ page.cfm?id=58\&nid=26 Accessed Jan. 30, 2008. 